\section{Royal Loan to British Museum}

Among recent additions to the collections of the British Museum (Bloomsbury), it is announced, are three ancient gold ornaments which have been placed on permanent loan by the King. Not only are these of great archæological value, but also they have the added interest that they came into the possession of the Crown during the nineteenth century under. the law of Treasure Trove. The oldest of the three, dating from about 1400 B.c., is a gold beaker with handle, standing about $3 \frac{1}{4}$ inches high, which was found in 1837, together with a bronze dagger and other objects, in a barrow at Rillaton Manor, Linkinhorne, Cornwall. Coming next in age is a gold torc of about the first century B.C., which is made of twisted strands of gold. It was found in Needwood Forest in 1848. The third exhibit is a pectoral cross and chain, known as the Clare reliquary, which was dug up at the site of Clare Castle, Suffolk, in 1866. It is of English workmanship of about A.D. 1400 . It has a pearl in each angle, and is stippled with a representation of the crucifixion in front and a floral pattern behind. It still contains pieces of the True Cross and the Rock of Calvary.

\section{Iranian Studies}

OWING in great measure to the exhibitions of Persian and Chinese art, which have been held at the Royal Academy, interest in Asiatic art, once exclusively confined to scholars and connoisseurs, is steadily spreading to a wider circle of the public. Not merely does it take the form of purely æsthetic appreciation ; it is rather an avenue to understanding of the culture and outlook of peoples hitherto regarded as far removed in more than merely a geographical sense. In this movement, the acquisition for the nation of the Eumorfopoulos collection of Chinese and Far Eastern art, of which the exhibition at South Kensington is proving markedly successful, has been an added stimulus. While London awaits its museum of Asiatic art, any addition to the facilities for study of the cultural achievement of the East is deserving of every encouragement. On this ground at least, students and others will welcome the announcement that friends of Iran have founded a society for the study of Iranian art on the lines of the Société des Etudes Iraniennes of Paris. Among those who are taking an active part are Lord Lamington, Sir Denison Ross, Mr. Laurence Binyon, Mr. Leigh Ashton and Prof. D. Talbot Rice. Those who are interested in the work of the society may communicate with the secretaries, Mr. Basil Gray and Mr. S. F. Shademan, at 10 Prince's Gate, S.W.7.

\section{Applied Physics}

THE March issue of the Review of Scientific Instruments devotes eleven pages to a report of the meeting of the Advisory Council on Applied Physics of the American Institute of Physics held in Pittsburgh in November. The Council recommended that in the American Physical Society a Division of Applied Physics be formed under a special chairman and committee to arrange for papers on applied physics to be read and discussed and to direct the journal Physics. In the discussion on the training of physicists for industrial posts, it was pointed out that at most of the American universities the average graduate in physics "lacks practical sense and initiative" as compared with the chemist or engineer, and "is inclined to overemphasise theory, quantum physics and atom splitting". A demand was made that "the applied physics student should be required to study more chemistry" in order that the present belief "that it is easier to train a chemist in the physics he needs than it is to train a physicist in the chemistry he needs" may be eradicated. Like the engineer, the chemist and the metallurgist, he should have courses in the practical application of his knowledge. The Council further resolved that meetings be held to discuss the outstanding problems of each industry and that the desirability of preparing a book "Physics in Overalls" be considered.

\section{Lancashire and Cheshire Fauna}

THE twenty-first annual report of the Lancashire and Cheshire Fauna Committee deals chiefly with 1934 records, and in addition to adding 146 new records to their faunal lists and 44 to one county, there are species new to Britain and to science. Of the Micro-Lepidoptera, a species bred by F. N. Pierce and W. Mansbridge from alpaca wool and wrongly considered Tinea merdella, Staint, is now found to be new to science and is named Tinea lanella, Pierce and Metcalfe. Scythris fallacella is a small moth new to Britain from the north Lancashire limestone. The amall pearl-bordered fritillary butterfly has reappeared in the Delamere Forest area of Cheshire after fifty years absence. Of Coleoptera, Anthicus tobias, Mars., previously recorded from India, Arabia, Mesopotamia and Turkey, and said to have been from rotten sacking in Kent previously, was found breeding in some numbers by Mr. H. Britten on the Manchester Corporation refuse dump. Fifteen new records of Mallophaga for the counties are added from studies of wild and domestic birds. Efforts are being made to find the Cooke collection of sawflies compiled in the area last century, in order to examine the material in the light of the committee's present knowledge of the Hymenoptera-Symphyta. Request is also made for shrews and bats for parasite study at the University of Manchester. The ornithological report for Lancashire and Cheshire includes little of wide interest compared to former years.

\section{Mining Research at Birmingham}

WE have received from the University of Birmingham the report on the work of the Mining Research Laboratory during the fifteen months to March 1935. The introduction explains how it is that the report ends with work done in March. The report especially discusses silicosis, pneumonoconiosis, etc., to which six pages out of twenty are devoted. Attention may be directed to the excellent article by Bax in Glückauf, page 1241, upon the methods used in combating silicosis in the Ruhr district. The report before us shows, like Mr. Bax's paper, that nothing definite is 
yet known as to the causes of silicosis, etc. The suggestion is made that the incidence of silicosis may in large measure be due to the riding of men on 'spakes'. The essential thing is that up to the end of December 1934 there have been a great many deaths in the country from silicosis, of which more than 50 per cent have occurred in the anthracite area of South Wales. Other subjects treated in the report before us are underground illumination, utilisation of coal by converting coke oven gas into gas with high calorific value, the quantity of firedamp in coal seams as worked, the pressure not having been investigated, spontaneous combustion in coal mines, control of atmospheric conditions in hot and deep mines, whilst investigations connected with the Gresford disaster apparently have occupied a great deal of the time and energies of the Research Laboratory, of which the late Prof. J. S. Haldane was director.

\section{Land Utilisation Survey}

THE fifth annual report of the Land Utilisation Survey of Britain has recently been published. It records the number of published sheets as thirty-two, with twenty more sheets scheduled for publication in the near future. The completed survey will comprise 235 sheets. Most of the field work has now been completed, but there are still gaps, notably in East Cornwall, Herefordshire, the West Riding and parts of Wales. It is planned to issue eventually eighty. seven county reports. These will analyse the distribution of each type of utilisation and, where information is available, compare to-day's conditions with those of the past. The utilisation of the land will be correlated with soil conditions. Each county report will be published at one shilling. It may be noted that the relevant maps have been called for by the Commissioner of the Special (Depressed) Areas in order to indicate what land is still available for settlement or development. The cost of publishing a sheet is roughly $£ 100$, and various county authorities and universities have made contributions to the sheets of their areas. In other cases the ordering of large numbers of sheets for educational purposes has enabled publication to take place. The director, Dr. Dudley Stamp, appeals for more help of this kind. The headquarters of the Survey is the London School of Economics, where offers of help should be addressed.

\section{Lasting Qualities of Printing Paper}

THIRTY-THREE years ago the Carnegie Institution of Washington, after careful inquiry, decided that papers made of rags of the best grade gave the greatest promise of durability, and since then the more important books published by the Institution have been printed upon specially made all-rag paper (Carnegie Inst., Washington, Report of Editor of Division of Publications for year 1934-35, p. 371). Increasing costs of such paper, together with the fact that the supremacy of all-rag paper has been challenged, led to a new investigation, which has just been completed. The value of rag paper is confirmed, for all investigators agreed about its satisfactory behaviour over long periods, but attention is directed to factors other than quality which affect the lasting property of paper. For example, disintegration is hastened when paper is stored in atmospheres rendered acidic by the presence of sulphur dioxide. It is recommended that permanent records should be stored under controlled atmospheric conditions of 50 per cent relative humidity and $70^{\circ}-75^{\circ} \mathrm{F}$. temperature. It is doubtful if paper made from chemically treated wood fibres would stand as well, but the evidence is not strong enough to induce the Institute to cast aside its rags.

\section{Tests on Wood Boxes and Crates}

THE United States Forest Products Laboratory has already undertaken detailed scientific and engineering tests on wood boxes and crates. Fibreboard boxes and other shipping containers are now to be subjected to similar tests, according to Science Service, of Washington, D.C. These latter now constitute business amounting to 165,000,000 dollars in the United States. It is said that these fibre boxes and containers are on a largely empirical basis, and the unavoidable losses are as yet unknown. The investigation will take place in the pulp and paper section of the Laboratory, since fibre box paper is largely made from waste, such as newsprint, in combination with new pulp. The strength tests of the paper will be carried out with the use of highly accurate scientific instruments. These include a Tuckerman optical strain gauge which, under rigidly controlled atmospheric humidity conditions, tells the degree of stiffness in small strips of paper. A tiny mirror, rotating as the paper is stretched, throws a beam of light on a small seale which indicates the amount of stretch. Strength formulæ so derived will be correlated with others obtained from tests on the strength of finished fibre boards, as well as others calculated from tests of completed boxes. A circular rotating drum will be used for tests on completed boxes, both full and empty; the drum when revolved jolts, drops, and slides boxes round in a fashion similar to the treatment they are subjected to in transit by rail, ship or lorry.

\section{Handbook of International Organisations}

A RECORD of international organisations is kept by the Section of International Bureaux of the League of Nations, and is published as a half-yearly "Bulletin of Information on the Work of International Organisations", and collected and compressed in a "Handbook of International Organisations", of which the last Supplement is dated 1931. The information contained relates not to work organised by the League but to the voluntary international societies_-_"organisations internationales privées"- - which exist outside the League, many of which are older than the League. They have an independent life of their own, but keep touch with the League. There appear to be certain features common to a number of these organisations and their conferences; for example, several of them feel the need of specialist international

(Continued on p. 821.) 